\title{
Advancement in Ozone base wastewater treatment technologies: Brief review
}

\author{
Kaushar Hussain ${ }^{1}$, Nadeem A Khan ${ }^{2}$, Viola Vambol ${ }^{3}$, Sergij Vambol ${ }^{3}$, \\ Sergiy Yeremenko ${ }^{5,}$, Volodymyr Sydorenko ${ }^{5}$ \\ ${ }^{1}$ Department of Civil Engineering, Mewat Engineering College, Nuh, Haryana, India-122107 \\ ${ }^{2}$ Department of Civil Engineering, Jamia Millia Islamia, New Delhi-110025 \\ ${ }^{3}$ Department of Applied Ecology and Environmental Sciences, National University «Yuri Kondratyuk Poltava \\ Polytechnic», Poltava, Ukraine \\ ${ }^{4}$ Department of Life Safety, State Biotechnological University, Kharkiv, Ukraine \\ ${ }^{5}$ Institute of Public Administration and Research in Civil Protection, Kyiv, Ukraine \\ ${ }^{*}$ corresponding author e-mail: esamns71@gmail.com
}

Received: 20 December 2021 / Accepted: 3 February 2022

\begin{abstract}
Over 70\% of the planet's surface is covered by water. A universal solvent, water can dissolve a wide variety of compounds. The majority of water contamination is caused by human activity. Increasing water use and pollution are to blame for the current shortage of fresh water supplies. Population expansion, agricultural runoff, and municipal wastewater are the primary sources of pollution in the river. To conduct the study, the logical chain was developed. For the review, open sources of scientific information were used. The focus was on publications from the last 10 years and at the same time; earlier works were taken into accounts that have useful information for this study, which were identified in the list of references when studying recent sources. The number of sources published earlier than 10 years ago does not exceed $7 \%$ of the total number of references. The present study aims to determine the optimum conditions for best removal of contaminants as the review focuses on advancement in Ozonation/AOP technology, different type of methods used for drugs removal and different operating condition. Various modern treatment procedures make extensive use of drinking water treatment plants. Water shortages in countries can be alleviated by implementing some of the recommendations made in the research. More catchment areas need to be developed; strict management policies and guidelines should be implemented. Ozonation can also more effectively remove certain personal care products (PPCPs) from the skin. Recycled water can be disinfected using ozonation, which breaks down ozone in water. When ozone is used in this way, it is an effective parasiticide, germicide, and virucidal agent. It can also remove the chroma compounds, smells, infections, and many micro-pollutants simultaneously. Ozone-based AOP should be studied in the future to see whether it is cost-effective and to see if it consumes more energy than other traditional treatment methods.
\end{abstract}

Keywords: ozone, treatment, hospital wastewater, AOP, technology, disinfection.

\section{Introduction}

Over $70 \%$ of the planet's surface is covered by water, making it an essential and plentiful resource. When it comes to the natural world, it's, as a rule, is in one of three states: liquid, gas, solid. When let to sit at room temperature, it has no smell and no taste but has a slight tint of blue (Z. Liu et al., 2021). A universal solvent, water can dissolve a wide variety of compounds. Water is a simple material in nature in all three general matter' states and is essential to all living organisms on our planet. It's a necessary part of the human body's structure (Khan et al., 2020). 
Furthermore, water makes up around $75 \%$ of the human body and is essential for extending life and maintaining homeostasis. A human's brain, lungs, and blood are composed of $95 \%, 90 \%$, and $82 \%$ correspondingly. A person as a living organism needs in many types of water's activities, namely: maintaining bodily lubrication, regulating temperature, eliminating toxic wastes, and delivering nutrients throughout the body (Cao et al., 2021). The majority of water contamination is caused by human activity. Drinkable water supplies and ecosystem preservation are under pressure due to human activity, the primary cause of stress on water systems. Increasing water use and pollution due to rapidly expanding societies are to blame for the current shortage of fresh water supplies (Kurian, 2021). Water supply and demand are changing. Future developments are unknown, but they are guaranteed to occur. Factors include the rising population and the enormous amount of water used per person in expanding sectors like home, urban, and industrial water usage are just a few. Population expansion, agricultural runoff, and municipal wastewater are the primary sources of pollution in the river - the primary contaminants, micro-pollutants, and diseases released into waterways. Microorganisms break down various organic materials and nutrients, resulting in a reduction in the amount of waste entering the environment. Due to this, the concentrations of viruses, bacteria and protozoa can be reduced by about 2.5, 3 and $2 \log 10$, respectively (Monteil et al., 2019; Yang et al., 2019; Zolfaghari et al., 2016).

Processing by traditional methods ensures that any harmful compounds or bacteria are completely removed from wastewater before being released into nature. Various modern treatment procedures make extensive use of drinking water treatment plants. An oxidation and disinfection process is also included in this list of methods. Pretreatment, coagulation, flocculation, filtration, sedimentation, and disinfection are all methods used to treat drinking water. Over the last several years, ozone has become an increasingly appealing and helpful technology with the advancements in water treatment technologies (Sardana et al., 2019; Souza \& Féris, 2016; Wang et al., 2009). Water may be disinfected using ozone-based technologies or ozonation procedures while degrading organic contaminants.

Ozonation may improve $\mathrm{pH}$, chemical oxygen demand (COD), and faecal coliform reduction in wastewater treatment and increase dissolved oxygen by a small amount after treatment. This type of disinfection, which is naturally oxidizing, can be used in place of chlorination since it has no harmful side effects and is highly effective. Ozone is a potent oxidizer, especially when radicals like hydroxyl radicals and nascent oxygen atoms. Simpler molecules are formed due to their direct or indirect reactions with more complex compounds (Achak et al., 2021; Hassan et al., 2020; Kozak et al., 2021). There is a growing interest in utilizing technologies that combine sophisticated oxidation processes such as ozone, hydrogen peroxide, and ultraviolet (UV) to destroy all pollutants. Traditional treatment procedures can't eliminate drugs from surface water and drinking water with conventional methods. Ozonation and AOP can degrade pharmaceutical compounds in water and wastewater. To eradicate $90 \%$ of antibiotic-resistant bacteria (ARB), chlorine requires $30 \mathrm{mg} / \mathrm{L}$, whereas ozone only requires $3 \mathrm{mg} / \mathrm{L}$. This means ozonation is a superior method in comparison to chlorination. Besides its disinfectant properties, ozone may also help remove iron and manganese from water and manage its colour, smell, and taste (Achak et al., 2021; Chiavola et al., 2014; Guvenc et al., 2019; Hassan et al., 2020; Kozak et al., 2021; Metropolitan Council Environmental Services, 2007). The present study aims to determine the optimum conditions for best removal of contaminants as the review focuses on advancement in Ozonation/AOP technology, different type of methods used for drugs removal and different operating condition.

\section{Methodology}

To conduct the study, the following logical chain was developed:

1) Using modern scientific sources, to find out if there is a need to apply ozone base wastewater treatment technologies;

2) Analyze the existing ozone base wastewater treatment technologies to understand whether these technologies are perfect or can be improved;

3) Having studied the latest achievements in the field of wastewater ozonation, substantiate its safety of use and the disinfection effectiveness;

4) Using modern scientific sources, to establish the factors affecting the ozonation process for wastewater;

5) Based on the information received, generate conclusions and prospects for the future.

For the review, open sources of scientific information were used. Sources were searched for relevant keywords. There were no restrictions on the scientific publication rating, indexing of publications in scientific databases, language, pages number of a publication, etc. The focus was on publications from the last 10 years and preference was given to publications with the highest citations. At the same time, earlier works were taken into accounts that have useful information for this study, which were identified in the list of references when studying recent sources. The number of sources published earlier than 10 years ago does not exceed $7 \%$ of the total number of references. 


\section{Need of Ozone based treatment and its advantages}

Water shortages in countries can be alleviated by implementing some of the recommendations made in the research. The following are a few options for water management: More catchment areas need to be developed, strict management practices and directives must be realized, limit on night water consumption, as well as water recycle-reuse measures, ensuring the harvesting and treatment of rainwater for use, using seawater to flush the toilet, separation of sources, detention, utilization and rational management of rainfall. Recuperation and multiple use of water, water processing, organic waste treatment for energy generation, heat regeneration, as well as nutrient recovery are only a few methods to help the environment (Grenoble et al., 2007; Ledjeri et al., 2016; Monteil et al., 2019). To satisfy the growing demand for water suitable for consumption and use in nations worldwide, particularly those experiencing water scarcity, effective water infrastructure maintenance, necessary management techniques, and cutting-edge remedial treatment technologies are necessary. In the future, ozone-based technologies may be used to clean water and wastewater, and they may help tackle the world's problem of water pollution and water shortages.

Additionally, ozone may be used to treat wastewater to eliminate organic pollutants, inorganic ions, and microorganisms from both surface and groundwater. Ozone oxidizes arsenic, iron, and manganese in water, forming an insoluble substance that filtering may remove, eliminating these contaminants. Coagulant, deodorizer, detoxifier, and disinfectant are just a few ozone uses. Additionally, ozone may be lowering biological oxygen demand (BOD) (and COD) and organic materials. Disinfection and decomposition of dissolved organic pollutants can be accomplished with the application of ozone. Ozonation can also more effectively remove certain personal care products (PPCPs) from the skin. Because $\mathrm{O}_{3}$ reacts quickly, it can form hazardous byproducts (such as bromide in saltwater or rotated and bromine in freshwater) and produce dissolved oxygen (DO) as a reaction result (Bashir et al., 2019; Bural et al., 2010; Lancheros et al., 2019; Li et al., 2020; Soomro et al., 2020; Tambosi et al., 2010).

Additionally, microflocculating tiny particles have been improved by increased biological processing of dissolved organic particles thanks to dissolved ozone in the water. When ozone is used in this way, it is an effective parasiticide, germicide, and virucidal agent. When $\mathrm{H}_{2} \mathrm{O}_{2}$ is present, ozone decay can yield the hydroxyl radical, a powerful oxidant used in water treatment. To break down ozone in water, a complex mechanism begins with the hydroxide ion's reaction, followed by the creation of radical oxidizing species (HO,
$\mathrm{H}_{2}$, and $\mathrm{H}_{3}$ ). There is no way to know how long $\mathrm{O}_{3}$ and the $\mathrm{HOx}$ structure will be present in a liquid water sample. Many of the disinfection technologies are borrowed from those used to treat drinking water in water recovery. Chlorination, membrane filtration, ozonation, and ultraviolet (UV) irradiation are examples of standard processes. The use of ozonation treatment technology in disinfecting reclaimed water is becoming increasingly commonplace across all of these approaches. With this method, bacteria, viruses, protozoans, spores, and prion protein may be effectively inactivated in water. When used to disinfect effluents from various wastewater treatment procedures, ozonation creates only a tiny number of disinfection by-products. Recycled water requires greater ozone dosages for disinfection than colour or odour reduction. Therefore, it is possible to remove the chroma compounds, smells, infections, and even many micropollutants simultaneously using the ozonation process. Most water treatment facilities across the globe use chlorine as a primary disinfectant to maintain the quality of their output (Elmolla \& Chaudhuri, 2012; Kurian, 2021; Lee et al., 2014; L. Liu et al., 2021).

Water and wastewater can benefit from ozone treatment using molecular $\mathrm{O}_{3}$ and hydroxyl radicals ( $\left.\mathrm{HO}\right)$. The higher the $\mathrm{pH}$, the more likely ozonation is an advanced oxidation process (AOP) because of the more significant concentration of $\mathrm{HO}$ radicals. The $\mathrm{O}_{3}$ molecule oxidation potential, which peer $2.07 \mathrm{~V}$ and the $\mathrm{HO}$ radicals oxidation potential, which peer $2.80 \mathrm{~V}$ indicate that they are such many powerful oxidants. The ozone is valuable in wastewater treatment because of its unique capacity to oxidize organic and inorganic molecules. To utilize $\mathrm{O}_{3}$ in various applications, such as water disinfection and odour elimination, you need to know that it has a wide range of oxidizing capabilities. Treatment and discharge of wastewater are handled using ozonation or ozone technology. To ensure maximum wastewater discharge, $\mathrm{O}_{3}$ is primarily used as an alternative to decolourization and disinfection with chlorine. Iron, manganese, nitrite and promoted are among the inorganic compounds that react to oxidize. Tertiary amines, thioethers and activated aromatics are electron-rich moieties that $\mathrm{O}_{3}$ interacts with. The ozone self-degradation can also respond with nonactivated aromatic molecules amides and alkenes and the activated aromatic compounds that have been active. One or more electrons are released in an oxidation process, which results in a material becoming oxidized. Because electrons cannot exist independently, they are accepted by another molecule that becomes reduced. As a result of its ancestry, $\mathrm{O}_{3}$ is inclined to receive electrons from other molecules (Gaurav et al., 2021; Khan et al., 2020).

Besides of disinfection, ozone is utilized in water treatment for colour, micro coagulation, odour, and taste, among other things. Compared to other chemical disinfectants, $\mathrm{O}_{3}$ 


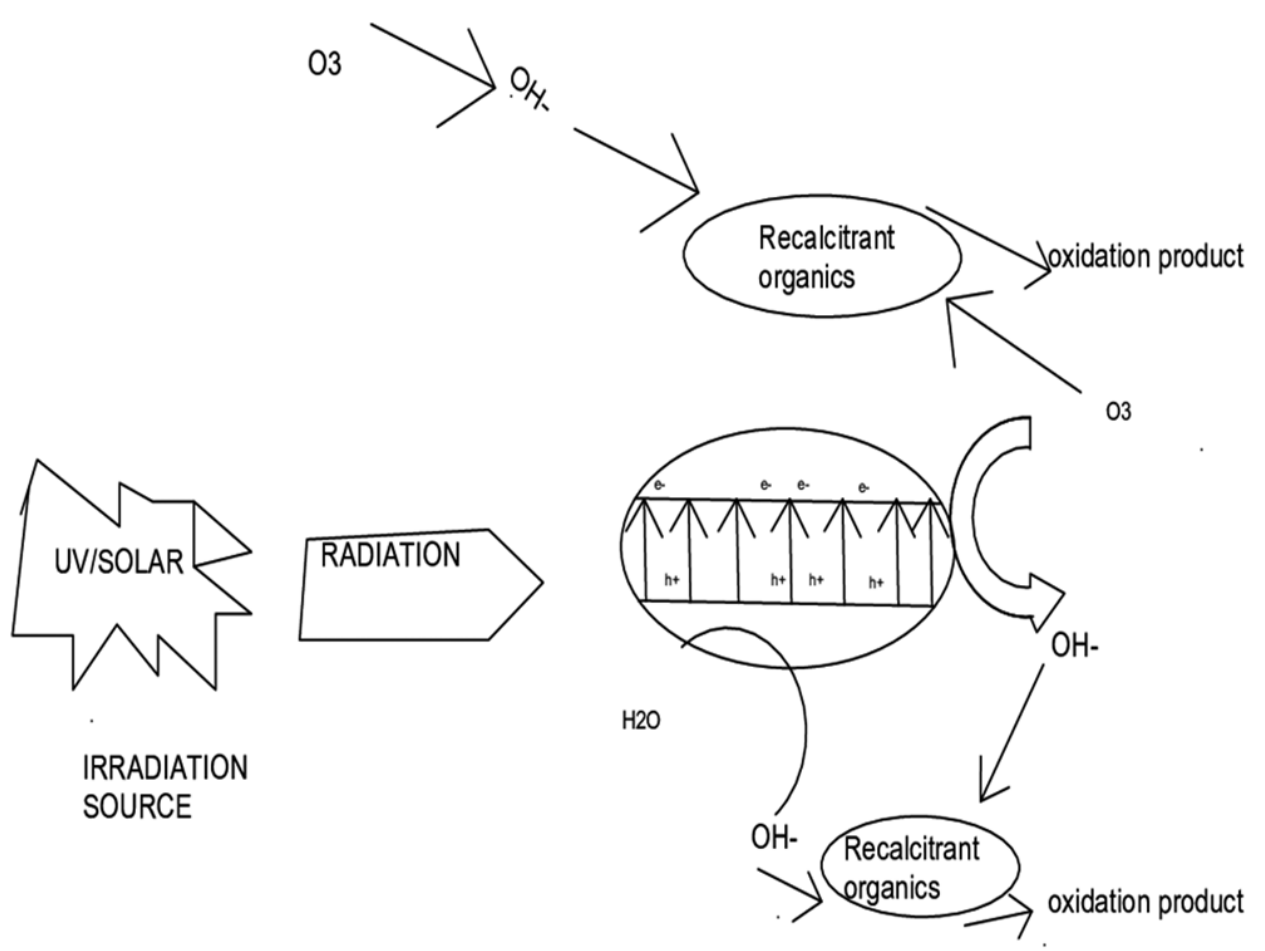

Figure 1. Photocatalytic Ozonation pictorial mechanism (Z. Liu et al., 2021)

wreaked havoc on bacteria and dormant viruses faster. As an oxidation potential of $2.07 \mathrm{~V}, \mathrm{O}_{3}$ is a highly redox-active molecule, and it can transfer electrons to other molecules, such as secondary oxidants (such as the HO radical). As a disinfectant, it can interact with many cell components, including the cell wall and DNA structure. Cultivable fungi, intl1 genes, and 16S rRNA may be eliminated by ozonation, whereas enterococci, enterobacteria, and heterotrophs can be eliminated by up to $4 \log$ units ozonation. Furthermore, the detection limit for antibiotic resistance genes may be decreased. Figure 1, illustrates the photocatalytic Ozonation mechanism.

\subsection{Advanced Oxidation Process (AOP), which is ozone based}

In most water purification plants worldwide; chlorine is utilized as the primary disinfectant. Recent research, however, suggests that when chlorine combines with any organic molecules present in water, it produces byproducts such as THMs, such as chloroform, for example. THMs increase free radical production entering the body, which is highly carcinogenic (Díaz et al., 2011). According to the United States Council on Environmental Quality, chlorinated water users face a $93 \%$ greater risk of cancer than non-users (Y. Li et al., 2021; Yan et al., 2021). As a result, approximately 280 major water purification facilities in the USA use $\mathrm{O}_{3}$ as a disinfectant. $\mathrm{O}_{3}$ is more powerful compared to chlorine and fulfils its function 3,000 times quicker than the latter. In treating ground, surface, or wastewater, ozone is used as a sole oxidant or in combination with energy or other oxidants. The ozone-based treatments methods aim to maximize apply of $\mathrm{O}_{3}$ to ameliorate disinfection or the disposal of existing impurities from the water.

A few of the benefits of ozone water treatment are as follows: (i) it can kill viruses and microorganisms in just a few seconds due to its high oxidizing strength and the quick response time required; (ii) after disinfection, this procedure contributes oxygen to the water; (iii) removes colour and odour and (iv) there's no need for additional chemicals to add taste; (v) It has no odour or flavour; (vi) it is pretty effective in eliminating germs. Sulphur and iron, for example, are oxidized by $\mathrm{O}_{3}$, allowing them to be sorted out of the solution. Oxidation of bacteria, moulds, organic substances, and other contaminants in water can be caused by $\mathrm{O}_{3}$, a very reactive gas. (vii) $\mathrm{O}_{3}$ is swiftly converted into oxygen and disappears after use (Sardana et al., 2019). For wastewater treatment, $\mathrm{O}_{3}$ and bio-filtration may offer the following advantages: (i) reduction of COD with low or tailored $\mathrm{O}_{3}$ doses and minimal operational costs; (ii) the oxygen used in activated sludge tank off-gas reduces operating expenses; (iii) due to the multiline input system's architecture, it consumes energy and oxygen (Wang et al., 2021).

Ozone treatment for potable water began in Japan with the first trials in two towns in Northern Kyusyo in the early 1930s. Because of high humidity and the high cost of 
power, it was not used. It began in the 1960s with Japan's industrialization. More than 17,000 water treatment facilities provide treated water over 16 billion $\mathrm{m}^{3}$ per year (Mostafa et al., 2021; Wong et al., 2013). Chlorination is now the only method of water disinfection that is required. The $\mathrm{O}_{3}$-GAC treatment technique is an innovative water treatment method available in Japan today (comprising membrane filtration). In all, ozone treatment facilities treat around $11 \%$ of the world's water supply. Kanzaki water treatment facility in Hyogo prefecture, Japan, was the first to use $\mathrm{O}_{3}$ for drinking water purification in 1973. More than 50 water treatment facilities have already used ozonation as a sophisticated treatment process to remove colour, taste, and odour and control the production of toxic heavy metals. These treatment facilities are operating satisfactorily. Since 2004, Japan has had a capacity of nearly $42,000 \mathrm{lb} /$ day $(800 \mathrm{~kg} / \mathrm{h})$ of ozone in the potable water purification. There were just three municipal ozone treatment plants in Japan in 1980, but that number grew to more than 50 in 2010 . Ozone was initially used in the United States in the early 1900s to treat drinking water to eliminate taste, colour, and odour, and it grew steadily until the mid-1980s when it took off. In 1987, the world's largest potable water plant with a capacity of 600 and $95,000 \mathrm{~m}^{3} / \mathrm{h}$ was put into operation in Los Angeles. By the end of 2010, the installed ozone treatment capacity reached over 525,000 $\mathrm{lb} /$ day. The first commercial use of $\mathrm{O}_{3}$ in drinking water purification dates back to 1954 when it was introduced in Canada. It was a French-made Otto Plate-type $\mathrm{O}_{3}$ generator used to cleanse the water. Sewage treatment using ozone as a microcontaminant remover is one possibility. Figure 2 shows the different type of Ozone based AOPs. Ozone is both a powerful disinfectant and a highly reactive oxidant. Since 1906, it has disinfected drinking water in Europe and several sewage treatment facilities (STPs). The introduction of ozone-based purification systems grew slowly until 1979, when Montreal developed a 9,600 lb/day $\mathrm{O}_{3}$ capacity $(182$ $\mathrm{kg} / \mathrm{h}$ ). A standing commission in 2008 concluded that a very effective oxidizer for the removal of viruses, bacteria, and harmful substances is ozonation. Table 1 illustrates the operating condition during different removal of drugs.

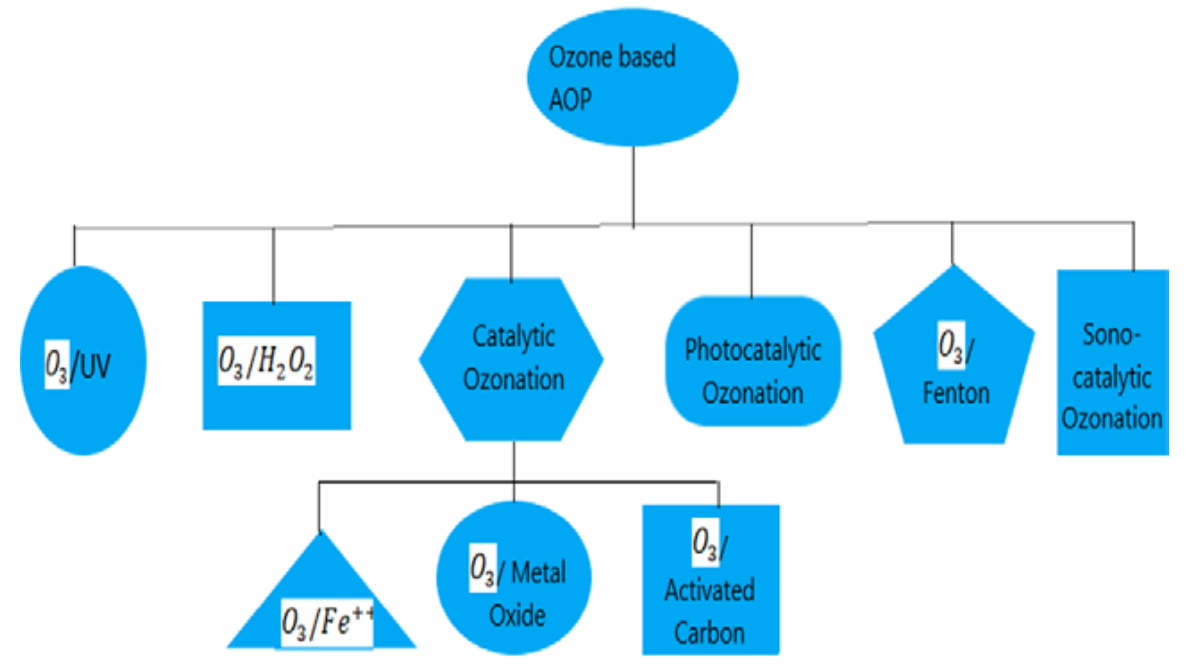

Figure 2. Ozone based AOP (Y.-L. Li et al., 2021; Wang et al., 2021)

Table 1. Operating condition during different removal of drugs

\begin{tabular}{|c|c|c|c|c|}
\hline Compounds to be removed & Catalyser & Performance & Working parameters & Source \\
\hline $\begin{array}{l}\text { Clofibric acid } \\
\mathrm{C}_{10} \mathrm{H}_{11} \mathrm{ClO}_{3} \\
\text { (herbicide) }\end{array}$ & $\mathrm{MnO}_{\mathrm{x}} / \mathrm{SBA}-15$ & TOC removal of $44 \%$ & $\begin{array}{l}\mathrm{pH} 3.7 \\
\mathrm{~T}=293 \mathrm{~K} \\
\mathrm{OD}=1.1 \mathrm{mg} / \mathrm{L} \\
\mathrm{CD}=0.3 \mathrm{~g} / \mathrm{L} \\
\mathrm{Rt}=14 \mathrm{~min}\end{array}$ & $\begin{array}{l}\text { Dordio et al. (2010), } \\
\text { Kimura et al. (2005) }\end{array}$ \\
\hline $\begin{array}{l}\text { Alachlor } \\
\mathrm{C}_{14} \mathrm{H}_{20} \mathrm{ClNO}_{2} \\
\text { (herbicide) }\end{array}$ & $\mathrm{Cu} / \mathrm{Al}_{2} \mathrm{O}_{3}$ & TOC removal of $76 \%$ & $\mathrm{pH} 4.3$ & $\begin{array}{l}\text { RS2 (2012), } \\
\text { Tete et al. (2020) }\end{array}$ \\
\hline $\begin{array}{l}\text { Carbolic acid } \\
\mathrm{C}_{6} \mathrm{H}_{5} \mathrm{OH} \\
\text { (antiseptic, disinfectant) }\end{array}$ & $\mathrm{Mn} / \gamma_{\gamma}-\mathrm{Al}_{2} \mathrm{O}$ & $\begin{array}{l}\text { Degradation efficiency } \\
\text { of } 63 \%\end{array}$ & $\begin{array}{l}\mathrm{T}=14{ }^{\circ} \mathrm{C} \\
\mathrm{OD}=6 \mathrm{mg} / \mathrm{min} \\
\mathrm{CD}=4 \%\end{array}$ & Kulkarni et al. (2013) \\
\hline
\end{tabular}


Table 1. Operating condition during different removal of drugs

\begin{tabular}{|c|c|c|c|c|}
\hline Compounds to be removed & Catalyser & Performance & Working parameters & Source \\
\hline $\begin{array}{l}\text { 4-Nitrophenol } \\
\mathrm{C}_{6} \mathrm{H}_{5} \mathrm{NO}_{3} \\
\text { (component of drugs, fungicides, } \\
\text { insecticides) }\end{array}$ & $\alpha-\mathrm{MnO}_{2}$ & $\begin{array}{l}\text { Degradation efficiency } \\
\text { of } 97 \% \text {; } \\
\text { TOC removal of } 79.5 \%\end{array}$ & $\begin{array}{l}\mathrm{pH} 3.4-5.8 \\
\mathrm{OD}=22 \mathrm{mg} / \mathrm{L}\end{array}$ & $\begin{array}{l}\text { Han et al. (2017), } \\
\text { Amado et al. (2019) }\end{array}$ \\
\hline $\begin{array}{l}\text { Acetamino-phen } \\
\mathrm{C}_{8} \mathrm{H}_{9} \mathrm{NO}_{2} \\
\text { (drug) }\end{array}$ & $\mathrm{MgO}$ & $\begin{array}{l}\text { Degradation efficiency of } \\
100 \% \text {; } \\
\text { Mineralization efficiency } \\
\text { of } 95 \%\end{array}$ & $\begin{array}{l}\mathrm{pH} 5.5 \\
\mathrm{OD}=55 \mathrm{mg} / \mathrm{L} \\
\mathrm{Rt}=12 \mathrm{~min}\end{array}$ & $\begin{array}{l}\text { Tambosi et al. (2010), } \\
\text { Paíga et al. (2016) }\end{array}$ \\
\hline \multirow{2}{*}{$\begin{array}{l}\text { p-Chloronitrobenzene } \\
\mathrm{C}_{6} \mathrm{H}_{4} \mathrm{ClNO}_{2} \\
\text { (drug) }\end{array}$} & $\begin{array}{l}\text { Iron silicate doped } \\
\text { hydroxylation iron }\end{array}$ & TOC removal of $62 \%$ & $\begin{array}{l}\mathrm{pH}=7.0 \\
\mathrm{OD}=0.5 \mathrm{mg} / \mathrm{L} \\
\mathrm{CD}=450 \mathrm{~g} / \mathrm{L} \\
\mathrm{Rt}=20 \mathrm{~min}\end{array}$ & Shirani et al. (2020) \\
\hline & $\begin{array}{l}\text { Mn oxide incorporated } \\
\text { ceramic membrane }\end{array}$ & $\begin{array}{l}\text { Degradation efficiency } \\
\text { of } 69 \%\end{array}$ & - & Holliger et al. (1997) \\
\hline $\begin{array}{l}\text { Norfloxacin } \\
\mathrm{C}_{16} \mathrm{H}_{18} \mathrm{FN}_{3} \mathrm{O}_{3} \\
\text { (drug) }\end{array}$ & $\mathrm{MnO}_{\mathrm{X}} / \mathrm{SBA}-15$ & $\begin{array}{l}\text { Mineralization efficiency } \\
\text { of } 55 \%\end{array}$ & \begin{tabular}{|l|}
$\mathrm{pH} 5$ \\
$\mathrm{~T} 298 \mathrm{~K}$ \\
$\mathrm{CD}=2 \%$ \\
$\mathrm{Rt}=60 \mathrm{~min}$ \\
\end{tabular} & $\begin{array}{l}\text { Chelme-Ayala et al. } \\
(2009)\end{array}$ \\
\hline \multirow{2}{*}{$\begin{array}{l}\text { Diclofenac } \\
\mathrm{C}_{14} \mathrm{H}_{11} \mathrm{Cl}_{2} \mathrm{NO}_{2} \\
\text { (drug) }\end{array}$} & $\begin{array}{l}\text { Iron silicate-loaded } \\
\text { pumice }\end{array}$ & $\begin{array}{l}\text { Mineralization efficiency } \\
\text { of } 72 \% \text {; } \\
\text { TOC removal of } 22 \%\end{array}$ & $\begin{array}{l}\mathrm{pH} 4.9 \\
\mathrm{OD}=4.052 \mathrm{mg} / \mathrm{L} \\
\mathrm{O} 2 \text { flow rate }-1.1 \mathrm{~L} / \mathrm{min} \\
\mathrm{CD}=8234 \mathrm{mg} / \mathrm{L} \\
\mathrm{Rt}=29 \mathrm{~min}\end{array}$ & Shirani et al. (2020) \\
\hline & Fe-MCM-41 & $\begin{array}{l}\text { Mineralization efficiency } \\
\text { of } 77 \% \text {; } \\
\text { TOC removal of } 72 \%\end{array}$ & $\begin{array}{l}\mathrm{pH} 7.1 \\
\mathrm{OD}=120 \mathrm{mg} / \mathrm{hr} \\
\mathrm{CD}=1.1 \mathrm{~g} / \mathrm{L} \\
\mathrm{Rt}=25 \mathrm{~min}\end{array}$ & Rosset et al. (2019) \\
\hline $\begin{array}{l}\text { Phenacetin } \\
\mathrm{C}_{10} \mathrm{H}_{13} \mathrm{NO}_{2} \\
\text { (drug) }\end{array}$ & $\mathrm{CuFe}_{2} \mathrm{O}_{4}$ & $\begin{array}{l}\text { Degradation efficiency } \\
\text { of } 94 \%\end{array}$ & $\begin{array}{l}\mathrm{pH} 7.2 \\
\mathrm{OD}=3.25 \mathrm{mg} / \mathrm{L} \\
\mathrm{Rt}=6 \mathrm{~min}\end{array}$ & Verlicchi et al. (2012) \\
\hline $\begin{array}{l}\text { Sulfamethazine } \\
\mathrm{C}_{12} \mathrm{H}_{14} \mathrm{~N}_{4} \mathrm{O}_{2} \mathrm{~S} \\
\text { (antibiotic) }\end{array}$ & Ce $1.0 \mathrm{Fe} 0.9 \mathrm{OOH}$ & $\begin{array}{l}\text { Mineralization efficiency } \\
\text { of } 42 \%\end{array}$ & $\begin{array}{l}\mathrm{pH} 7.2 \\
\mathrm{OD}=19 \mathrm{mg} / \mathrm{L} \\
\mathrm{CD}=0.3 \mathrm{~g} / \mathrm{L} \\
\mathrm{Rt}=20 \mathrm{~min}\end{array}$ & Sipma et al. (2010) \\
\hline $\begin{array}{l}\text { Sulfamethoxazole } \\
\mathrm{C}_{10} \mathrm{H}_{11} \mathrm{~N}_{3} \mathrm{O}_{3} \mathrm{~S} \\
\text { (antibiotic) }\end{array}$ & $\mathrm{Mn}-\mathrm{Ce}-\mathrm{O}$ & COD removal of $70 \%$ & $\begin{array}{l}\mathrm{pH} 6.8 \\
\mathrm{OD}=121 \mathrm{mg} / \mathrm{hr}\end{array}$ & Li et al. (2020) \\
\hline $\begin{array}{l}\text { Acid Orange II } \\
\mathrm{C}_{16} \mathrm{H}_{11} \mathrm{~N}_{2} \mathrm{NaO}_{4} \mathrm{~S} \\
\text { (azo dye) }\end{array}$ & $\mathrm{MgFe}_{2} \mathrm{O}_{4}$ & $\begin{array}{l}\text { Degradation efficiency } \\
\text { of } 92 \%\end{array}$ & pH 4.5...9.5 & Mozaffari et al. (2020) \\
\hline \multirow{2}{*}{$\begin{array}{l}\text { Methylene blue } \\
\mathrm{C}_{16} \mathrm{H}_{18} \mathrm{ClN}_{3} \mathrm{~S} \\
\text { (thiazine dye) }\end{array}$} & Fe-Mn & $\begin{array}{l}\text { Decolourization of } 100 \% \text {; } \\
\text { TOC removal of } 64-75 \%\end{array}$ & $\begin{array}{l}\mathrm{OD}=1.62 \mathrm{mg} / \mathrm{min} \\
\mathrm{CD}=0.549 \mathrm{~g}\end{array}$ & Zubair et al. (2017) \\
\hline & $\mathrm{MgO}$ & COD removal of $52 \%$ & $\begin{array}{l}\mathrm{OD}=6 \mathrm{mg} / \mathrm{L} \\
\mathrm{Rt}=70 \mathrm{~min}\end{array}$ & Iqbal et al. (2001) \\
\hline $\begin{array}{l}\text { Fulvic acid } \\
\text { (toxic organic compound) }\end{array}$ & $\mathrm{CeO}_{2} /$ Activated Carbon & $\begin{array}{l}\text { Degradation efficiency } \\
\text { of } 82 \%\end{array}$ & 4.95\% Ce loading & Qian et al. (2016) \\
\hline $\begin{array}{l}\text { Oxalic acid } \\
\mathrm{C}_{2} \mathrm{H}_{2} \mathrm{O}_{4} \\
\text { (toxic organic compound) }\end{array}$ & Fe-MCM-41 & \begin{tabular}{|l|} 
Degradation efficiency \\
of $95 \%$; \\
TOC removal of $6 \%$ \\
\end{tabular} & $\begin{array}{l}\mathrm{OD}=21.5 \mathrm{mg} / \mathrm{L} \\
\mathrm{CD}=0.3 \mathrm{~g} \\
\mathrm{Rt}=25 \mathrm{~min}\end{array}$ & Park et al. (2018) \\
\hline $\begin{array}{l}\text { Sulfosalicylic acid } \\
\mathrm{C}_{7} \mathrm{H}_{6} \mathrm{O}_{6} \mathrm{~S} \\
\text { (toxic organic compound) }\end{array}$ & $\mathrm{MnO}_{2} / \mathrm{CeO}$ & TOC removal of $98 \%$ & $\begin{array}{l}\mathrm{pH} 6.5 \\
\mathrm{Rt}=25 \mathrm{~min}\end{array}$ & $\begin{array}{l}\text { Chelme-Ayala et al. } \\
(2009)\end{array}$ \\
\hline $\begin{array}{l}\text { 4-Chlorophenol } \\
\mathrm{C}_{6} \mathrm{H}_{4} \mathrm{BrClO} \\
\text { (organic compound) }\end{array}$ & $\mathrm{MgO}$ & TOC removal of $99.5 \%$ & $\begin{array}{l}\mathrm{pH} 6.3 \\
\mathrm{OD}=2.4 \mathrm{mg} / \mathrm{min} \\
\mathrm{CD}=1.1 \mathrm{~g} / \mathrm{L}\end{array}$ & $\begin{array}{l}\text { Karimi-Maleh et al. } \\
\text { (2019), Chelme-Ayala et } \\
\text { al. (2009) }\end{array}$ \\
\hline
\end{tabular}

Note: TOC - Total Organic Carbon removed; COD - Chemical oxygen demand; BOD - Biological oxygen demand; OD - Ozone Dose; CD - Catalyst Dose; Rt - Reaction time 


\section{Ozone-based treatment for disinfection}

Many fungi have a function to play in the development of human illnesses. Other species, such as moulds and bacteria, can change food and make it unsuitable for consumption. The ozone treatment was delivered at varying concentrations and temperatures when treating Aspergillus flavus, Candida aspergidae, Clostridium chauvei, and Tricophyton verrucosum with Ozone as well as at varying contact times for each fungus. Aspergillus flavus (78 per cent) and Candida albicans (90\%) may be reduced by $\mathrm{O}_{3}$ concentrations of 1.5 and 60 $\mathrm{mg} / \mathrm{L}$, respectively (Gaurav et al., 2021; Giannakis et al., 2021; Xie et al., 2021). As the most common disinfection method, chlorination has a few downsides, including the necessity for a large amount of disinfectant and the potential for dangerous byproducts to be formed. Ozone and photobased methods have received significant attention for disinfection in recent years. Ozone can inactivate a wide range of pathogens, including bacteria, protozoa, viruses, and prion protein, as well as their spores and other parts. Compared to chlorine, $\mathrm{O}_{3}$ disinfection is superior, with shorter response times and no regrowth of microbiological organisms. As a result, any remaining $\mathrm{O}_{3}$ decays fast into $\mathrm{O}_{2}$ and do not pose any danger. Compared to protozoa, viruses and bacteria are far more sensitive to $\mathrm{O}_{3}$ oxidation, which requires less ozone to kill them. Because of this, $\mathrm{O}_{3}$ is an excellent bactericidal agent for both infections and bacterium inactivation. Microorganisms like Escherichia coli, Adenoviruses, Coxsackieviruses and Echovirus, and protozoa like Cryptosporidium parvum, and Giardia muris can be eliminated with $\mathrm{O}_{3}$ processing technology. E. coli, Shigella spp., Salmonella spp., and Vibrio cholera were inactivated in synthetically water and secondary domestic sewage using solar and UV titanium dioxide photocatalytic ozonation. The Photocatalytic ozonation effectively inactivated the bacteria and also constructive synergistic relations, resulting in synergy indices of equal to 1.86 , which represents a performance significantly larger than that of photocatalysis and ozonation individually (Elmolla \& Chaudhuri, 2012; L. Liu et al., 2021). Additionally, ozone-based therapy is effective in killing other microbes. $\mathrm{OH}$, radicals and hydrogen peroxy $\left(\mathrm{HO}_{2}\right)$ radicals are formed during the ozone decomposition process, and these radicals have an important disinfectant function. Plausible hypothesis: Bacteria are smashed because of cell wall degradation caused by protoplasmic oxidation (cell lysis). Some factors such as contact time, target organism susceptibility, and $\mathrm{O}_{3}$ concentration determine disinfection efficacy. Research shows that the design of $\mathrm{O}_{3}$ as the main therapy must incorporate the basic requirements of $\mathrm{O}_{3}$, $\mathrm{O}_{3}$ residual, and the shortest contact time for meeting required cyst and viral inactivation needs, as proven in this study (Kurian, 2021; Paumo et al., 2021). There should be an on-site ozone production, which is used in the water flow through appropriate liquid/gas contact conditions. $\mathrm{O}_{3}$ is an effective disinfectant because it destroys the germs essential components through oxidation processes. Using $\mathrm{O}_{3}$ to disinfect can cause and disrupt the functioning of the bacterial cell membrane, enzymes, and relationships between cells inside the bacterial cell. Although the disinfectant's common effect on bacteria and other well-known organisms, the precise mechanisms of action have not yet been determined. As for viral disinfection, the oxidative assault on the protective protein covered by ozone is being addressed; interactions with deoxyribonucleic acid or ribonucleic acid may also be an important consideration (Cao et al., 2021; Domingues et al., 2021; Lu et al., 2021). The primary goal of ozonation in water treatment facilities is to acquire disinfection log-inactivation credit for various species, such as cryptosporidium, giardia, and viruses, at levels regulated or higher than regulated. 1-log inactivation is comparable to $90 \%$ inactivation, while $2-\log$ is $99.9 \%, 3-\log$ inactivation is $99.9 \%$, and so on. Generally, the word log inactivation or elimination is used in regulations to simplify reporting of disinfection. Pathogens and heterotrophic bacteria must be controlled by an internal disinfection procedure in the aquaculture recirculation system. In a reusing water system, the effectiveness of Ozone alone and Ozone after which there should be UV radiation was tested to observe which was more effective in reducing heterotrophic and total coliform bacteria (Cao et al., 2021; Domingues et al., 2021; Giwa et al., 2021; Joseph et al., 2021; Lu et al., 2021; Mouele et al., 2021).

\section{Factors affecting the Ozonation process for wastewater}

Several researchers have studied the ozonation process' effectiveness. Many parameters, including the initial $\mathrm{O}_{3}$ accumulation, dosing techniques of $\mathrm{O}_{3}, \mathrm{pH}$, duct and temperature, all affect the decay rate of $\mathrm{O}_{3}$. Temperature and $\mathrm{pH}$ have an impact on the efficiency of ozonation processes. As a result of the breakdown of molecular $\mathrm{O}_{3}$ into highly reactive species such as $\mathrm{HO}_{2} \bullet$ and $\mathrm{HO} \cdot$, the $\mathrm{O}_{3}$ occurs under acidic circumstances (lower $\mathrm{pH}$ ). In comparison to the reaction rate of molecular $\mathrm{O}_{3}, \mathrm{HO} \cdot$ is a particularly important oxidant since its assault is 106-109 times faster. $\mathrm{pH}$ affects the ratio of $\mathrm{O}_{3}$ and $\mathrm{OH}$ radicals in wastewater (Rekhate \& Srivastava, 2020; Tripathi \& Hussain, 2022). Because the increase in $\mathrm{pH}$ increases the concentration of $\mathrm{OH}$ radicals, An increase in $\mathrm{pH}$ also impacts the reactivity of certain medications. When $\mathrm{pH}$ rises, amines become more reactive due to increased electronegativity; for example, in deionized water, scavengers have been introduced to monitor the optimal $\mathrm{pH}$ at which the pace of reaction can 
be observed (Haq et al., 2021; Keyan et al., 2021). In $\mathrm{O}_{3}$ disinfection, $\mathrm{pH}$ may be an important factor. Even though the quality of sterilization at a specific concentration of $\mathrm{O}_{3}$ solution is not considered to alter significantly across $\mathrm{pH}$, it is not immediately obvious. Additionally, if $\mathrm{O}_{3}$ decay rates rise above a certain $\mathrm{pH}$ level, so will the dosage needed to achieve a disinfection objective for $\mathrm{O}_{3}$. This is important to keep in mind. Under high $\mathrm{pH}$ conditions, disinfection can still be achieved due to the rapid action of $\mathrm{O}_{3}$. According to another research, COD was found to be lowered from $48 \%$ to $39 \%$ throughout the ozonation process, while the $\mathrm{pH}$ was raised from 6 to 7 and then elevated from 8 to 57 per cent. In general, the COD removal percentage remained nearly unchanged at pH levels over 8 (Hansen et al., 2021; Köhler et al., 2012). Dye degradation and COD removal at $\mathrm{pH} 6$ are linked to dye molecule-mediated direct oxidation of $\mathrm{O}_{3}$, which is the primary chemical route leading to an acidic state. As $\mathrm{pH}$ increased, COD elimination was also boosted. $\mathrm{O}_{3}$ breakdown has also been linked to an increase in the generation of reactive radicals. The effects of ozonation may be attributed to a change in $\mathrm{pH}$ and carbonate concentration rather than a direct interaction of $\mathrm{O}_{3}$. Natural organic matter (NOM), pH, amount and category, solidity and coagulation conditions (a kind of coagulant, quantity) can all majorly impact the impacts of ozonation on raw water quality indicators (Luo et al., 2021; Rekhate \& Srivastava, 2020). Various elements influence the response mechanism and rates, as evidenced by several researches. $\mathrm{O}_{3}$ 's ability to oxidize inorganic and organic compounds depends on the water's $\mathrm{pH}$ and temperature. Among the many variables that must be taken into account when using wastewater are $\mathrm{BOD} / \mathrm{COD}, \mathrm{pH}$, water temperature, TSS, heavy metals, and so on. $\mathrm{O}_{3}$ reacts primarily as the $\mathrm{O}_{3}$ molecule in low $\mathrm{pH}$ (less than 7) through selective and temporarily sluggish reactions. It breaks down into free radicals at high (greater than 8) pH levels, reacting very quickly. Oxidation of various composites is accelerated when the $\mathrm{pH}$ is adjusted towards the alkaline side. Organic particles can be oxidized at a $\mathrm{pH}$ between 8 and 10. The $\mathrm{O}_{3}$ inactivation of the virus, taking into account $\mathrm{pH}$ and temperature. More than $\mathrm{pH}(6.5$ to 8.5 ) and temperature ( 2 to $22^{\circ} \mathrm{C}$ ) were tested for MS2 inactivation, similar to the treatment characteristics of water and wastewater. As a result, the inactivation was sped up by increasing $\mathrm{pH}$ and temperature. Direct dyestuff wastewaters were shown to decolourize at a $\mathrm{pH}$ of 12 and above (basic condition). Using a high flow rate of $\mathrm{O} 3$ resulted in a large number of bubbles; as a result, $\mathrm{O}_{3}$ treatment is ideal for the decolourization of dyestuff effluent. Ozone treatment is also affected by temperature (Khan et al., 2020; Vieira et al., 2021; Xie et al., 2021). The constant increase in the reaction rate and temperature-dependent variations in $\mathrm{O}_{3}$ solubility combine to produce the net influence that temperature has on ozonation. $\mathrm{O}_{3}$ is less soluble at higher temperatures, reducing the amount of $\mathrm{O}_{3}$ available for reactions that can result in a total reduction in deterioration. The difference in solubility between $\mathrm{O}_{3}$ and organics slows down processes. At higher temperatures, the reaction rate rises, but the solubility of $\mathrm{O}_{3}$ is not much impacted. Despite this, the COD removal is unaffected significantly up to $40^{\circ} \mathrm{C}$ because the pace of reaction is compensated by lowering the solubility of $\mathrm{O}_{3}$

Table 2. Application of ozone based AOP for treatment of various wastewater

\begin{tabular}{|c|c|c|c|c|}
\hline Wastewater & Treatment method & Performance & Working parameters & Source \\
\hline Gas Station & UV/O3/TiO2 & $92 \%$ DOC & $\mathrm{OD}=15.3 \mathrm{mg} / \mathrm{L} ; \mathrm{CD} .0 .31 \mathrm{~g} / \mathrm{L}$ & Rivas et al.(2012) \\
\hline Hospital & O3+ hydrogen peroxide & $\begin{array}{l}100 \% \text { removal of } \\
\text { cytostatic compound }\end{array}$ & $\begin{array}{l}\mathrm{OD}=53 \mathrm{~g} / \mathrm{m} 3 ; \mathrm{pH} 8 ; \text { Reaction } \\
\text { time } 22 \mathrm{~min}\end{array}$ & Khan et al. (2021) \\
\hline Pesticide Industry & $\mathrm{TiO} / \mathrm{O} 3 / \mathrm{UV}$ & $\begin{array}{l}98 \% \text { for malathion \& } \\
\text { parathion }\end{array}$ & $\begin{array}{l}\mathrm{OD}=1.52 \mathrm{mg} / \mathrm{L} ; \mathrm{pH} 8 ; \text { Reaction } \\
\text { time } 32 \mathrm{~min}\end{array}$ & Rivas et al. (2012) \\
\hline Petrochemical & $\mathrm{O} 3$ & $38 \%$ DOC & $\begin{array}{l}\mathrm{OD}=12 \mathrm{mg} / \mathrm{L} ; \text { Reaction time } 4 \\
\mathrm{~min}\end{array}$ & Legrini et al. (1993) \\
\hline Piggery & 03 & $\begin{array}{l}52 \% \text { increase in light } \\
\text { transmittance of liquid }\end{array}$ & $\mathrm{OD}=1.12 \mathrm{mg} / \mathrm{L}$ & Legrini et al. (1993) \\
\hline Pharmaceutical & O3/TiO2/UV-A & $\begin{array}{l}\text { 100\% diclofenac } \\
\text { removal \& } 92 \% \text { TOC } \\
\text { removal }\end{array}$ & $\begin{array}{l}\text { TiO2 Cons. } 1.45 \mathrm{~g} / \mathrm{L} ; \mathrm{pH}=7.1 \text {; } \\
\text { Ozone } 1.1 \mathrm{mg} / \mathrm{L}\end{array}$ & $\begin{array}{l}\text { Rekhate and Srivastava (2020), } \\
\text { Tripathi and Hussain (2022) }\end{array}$ \\
\hline Petrochemical & $\mathrm{Fe}++-\mathrm{BAF}$ & $68 \%$ for TSS & $\begin{array}{l}\mathrm{OD}=25 \mathrm{mg} / \mathrm{L} ; \mathrm{Fe}++ \text { dosage } 0.08 \\
\mathrm{mmol} / \mathrm{L}\end{array}$ & $\begin{array}{l}\text { Rekhate and Srivastava (2020), } \\
\text { Tripathi and Hussain (2022) }\end{array}$ \\
\hline Textile dyeing & $\begin{array}{l}\text { Carbon aerogel support- } \\
\text { ed cobalt oxide }\end{array}$ & $82 \%$ for COD & $\begin{array}{l}\mathrm{OD}=2.12 \mathrm{mg} / \mathrm{min} ; \mathrm{CD}=3.2 \mathrm{~g} \\
\mathrm{~T} 24^{\circ} \mathrm{C}\end{array}$ & Ercan et al. (2015) \\
\hline Textile & $\begin{array}{l}\text { Carbon aerogel support- } \\
\text { ed copper oxide }\end{array}$ & $48 \%$ for COD & - & $\begin{array}{l}\text { Rekhate and Srivastava (2020), } \\
\text { Tripathi and Hussain (2022) }\end{array}$ \\
\hline Municipal & Iron Shaving (Feo) & $\begin{array}{l}1.23 \text { times greater } \mathrm{COD} \\
\text { removal efficiency than } \\
\mathrm{O} 3\end{array}$ & - & Mackulak et al. (2015) \\
\hline
\end{tabular}


in water. However, beyond $50^{\circ} \mathrm{C}$, the reaction rate begins to slow as the solubility decreases and the rate of reaction increases. Numerous catalysts, including electrocoagulation, $\mathrm{H}_{2} \mathrm{O}_{2}$, semi-precious, gold, and ultrasonically agitated, are applied together with $\mathrm{O}_{3}$. Other wavelengths of UV light may be employed, such as $254 \mathrm{~nm}$. It was discovered that the numerous complexes that neither $\mathrm{O} 3$ nor UV alone can destroy; however, $\mathrm{UV}$ and $\mathrm{O}_{3}$ together could be eliminated as well, and the elimination rate is rapid, for a moment in as little as two seconds. There's no doubt that the dissolved effluent organic matter, suspended particles, and microbial complexity in the wastewater may be the key factors influencing the efficacy of ozonation treatment. The ozonation process was shown to be significantly $\mathrm{O}_{3}$ dosage and contact time sensitive, just as predicted. Organic carbon may have a scavenger or promoter role in ozonation reactions. As a general rule, many organic carbon results in lower oxidation rates. COD and DOC are commonly used to characterize the organic carbon during the oxidation process. The COD is decreased when organic complexes are oxidized, but the composite is usually not mineralized. Thus the DOC reduction is negligible. Additionally, turbidity is a critical factor to consider when evaluating a sample. When particles are suspended in a fluid and their cloudiness is measured, it is known as cloudiness. Cloudy effluent with a high turbidity level may indicate a fault in the treatment process and a lack of control over the process. Table 2 shows the application of ozone based AOP for treatment of various wastewater. There are two ways in which inorganic salts might influence ozonation through inorganic salts: as a mass transfer or as a scavenger or booster of the process. Due to their ability to increase the surface area of bubbles, salts can reduce their coalescence, therefore increasing their mass transfer rate (Domingues et al., 2021; Giannakis et al., 2021).

Table 3. Statistical Summary

\begin{tabular}{|l|c|c|c|c|}
\hline \multicolumn{1}{|c|}{ Moving Average } & Min $(\mathbf{m m})$ & Max $(\mathbf{m m})$ & Mean $(\mathbf{m m})$ & SD $(\mathbf{m m})$ \\
\hline 2 years & 90.55 & 529.90 & 226.2297 & 105.74284 \\
\hline 3 years & 101.47 & 440.53 & 226.8270 & 90.66437 \\
\hline 4 years & 120.50 & 378.80 & 227.3574 & 81.04385 \\
\hline 5 years & 126.44 & 355.44 & 226.2604 & 74.14263 \\
\hline 10 years & 81.85 & 306.65 & 208.3212 & 66.12177 \\
\hline Observed & 84.80 & 639.50 & 227.3189 & 133.07741 \\
\hline
\end{tabular}

\section{Conclusion and Future prospects}

Chromatographic methods like GC and HPLC should help identify reaction intermediates. With these approaches, it is possible to study the therapy process in great detail. Tests for toxicity of intermediate/transformation products should be carried out at various phases of treatment to ensure that these compounds do not pose a risk.

For the treatment of a wide range of industrial effluents, hybrid technologies are a cost-effective option. Using a single reactor for Fenton/UV/photocatalytic oxidation and ozonation instead of two separate reactors reduces capital costs for reactors and associated accessories. Operational costs are reduced, $\mathrm{OH}$ supply is improved, and treatment efficiency is increased using a combination procedure. Activated sludge, adsorption, and chemical coagulation are just a few of the standard treatment methods that may be used to remove contaminants from wastewater, even though they have several drawbacks, such as the high cost of operating. Currently, many methods of disinfection used in water recovery are derived from those used in water treatment for human consumption. Other standard processes include chlorination, ozonation, and Ultra Violet (UV) light irradiation.
It is becoming more and more common to use ozonebased disinfection technologies in recovered water disinfection. Potable water and wastewater are treated with ozone because they are potent oxidants capable of removing organic contaminants and inorganic ions. It is being used as a disinfectant and a flavour and odour neutralizer. Ozonebased therapy is particularly effective in removing germs, protozoa, and viruses. Advances in Oxidation Processes employ oxidizing agents such as $\mathrm{H}_{2} \mathrm{O}_{2}, \mathrm{O}_{3}$, and $\mathrm{UV}$ radiation, or the combined use of these oxidants in chemical processes, to oxidize organic compounds (AOP). Industrial applications of AOPs include colour removal and COD reduction. Using this technology is the primary reason for its many qualities, including strong oxidizing power, short reaction time, quick disinfection, oxygen supply to the water following disinfection, colour and odour removal, chemicals not required, oxidizes to manganese and iron, reduce BOD and COD, no smell produce, and so on. Research in this area is needed to enhance these technologies further.

Ozone-based AOP should be studied in the future to see whether it is cost-effective and to see if it consumes more energy than other traditional treatment methods. To identify scale-up parameters, it is necessary to conduct further pilotplant size tests using genuine industrial wastewater. Efficient 
systems for ozone detection and destruction are essential to ensure the safety and well-being of workers in various processing industries since ozone exposure can cause eye or nose/throat discomfort, while excessive ozone levels can even be lethal to humans.

\section{References}

Achak M., Chhiti Y., Ezzahrae F., Alaoui M., Barka N. \& Boumya W., 2021, SARS-CoV-2 in hospital wastewater during outbreak of COVID-19: A review on detection, survival and disinfection technologies. Sci. Total Environ. 761: 143192. https://doi.org/10.1016/j. scitotenv.2020.143192

Amado C.M., Minahk C.J., Cilli E., Oliveira G. \& Dupuy F.G., 2019, Jo ur 1 P re. BBA - Biomembranes, 183135. https:// doi.org/10.1016/j.bbamem.2019.183135

Bashir M.J., Lim J.H., Abu Amr S.S., Wong L.P. \& Sim Y.L., 2019, Post treatment of palm oil mill effluent using electro-coagulation-peroxidation (ECP) technique. J. Clean. Prod. 208: 716-727. https://doi.org/10.1016/j. jclepro.2018.10.073

Bural C.B., Demirer G.N., Kantoglu O. \& Dilek F.B., 2010, Treatment of opium alkaloid containing wastewater in sequencing batch reactor (SBR)-Effect of gamma irradiation. Radiat. Phys. Chem. 79: 519-526. https://doi. org/10.1016/j.radphyschem.2009.09.013

Cao Y., Qiu W., Li J., Jiang J. \& Pang S., 2021, Review on $\mathrm{UV} /$ sulfite process for water and wastewater treatments in the presence or absence of O2. Sci. Total Environ. 765: 142762. https://doi.org/https://doi.org/10.1016/j. scitotenv.2020.142762

Chelme-Ayala P., Afzal A., Pourrezaei P., Wang Y., Zapata M.A., Ding N., Jin J., Wang N., Drzewicz P. \& El-Din M.G., 2009, Physico-chemical processes. Water Environ. Res. 81: 1056-1126. https://doi.org/10.2175/10614300 9X12445568399451

Chiavola A., Farabegoli G. \& Antonetti F., 2014, Biological treatment of olive mill wastewater in a sequencing batch reactor. Biochem. Eng. J. 85: 71-78. https://doi. org/10.1016/j.bej.2014.02.004

Díaz V., Ibáñez R., Gómez P., Urtiaga A.M. \& Ortiz I., 2011, Kinetics of electro-oxidation of ammonia-N, nitrites and COD from a recirculating aquaculture saline water system using BDD anodes. Water Res. 45: 125-134. https://doi.org/10.1016/j.watres.2010.08.020

Domingues E., Fernandes E., Gomes J. \& Martins R.C., 2021, Advanced oxidation processes perspective regarding swine wastewater treatment. Sci. Total Environ. 776: 145958. https://doi.org/https://doi.org/10.1016/j. scitotenv.2021.145958
Dordio A., Carvalho A.J.P., Teixeira D.M., Dias C.B. \& Pinto A.P., 2010, Removal of pharmaceuticals in microcosm constructed wetlands using Typha spp. and LECA. Bioresour. Technol. 101: 886-892. https://doi. org/10.1016/j.biortech.2009.09.001

Elmolla E.S. \& Chaudhuri M., 2012, The feasibility of using combined Fenton-SBR for antibiotic wastewater treatment. Desalination 285: 14-21. https://doi. org/10.1016/j.desal.2011.09.022

Ercan Ö., Deniz S., Yetimoğlu E.K. \& Aydın A., 2015, Degradation of Reactive Dyes Using Advanced Oxidation Method. CLEAN - Soil, Air, Water 43: 1031-1036. https:// doi.org/10.1002/clen.201400195

Gaurav G.K., Mehmood T., Kumar M., Cheng L., Sathishkumar K., Kumar A. \& Yadav D., 2021, Review on polycyclic aromatic hydrocarbons (PAHs) migration from wastewater. J. Contam. Hydrol. 236: 103715. https:// doi.org/https://doi.org/10.1016/j.jconhyd.2020.103715

Giannakis S., Lin K.-Y.A. \& Ghanbari F., 2021, A review of the recent advances on the treatment of industrial wastewaters by Sulfate Radical-based Advanced Oxidation Processes (SR-AOPs). Chem. Eng. J. 406: 127083. https://doi.org/ https://doi.org/10.1016/j.cej.2020.127083

Giwa A., Yusuf A., Balogun H.A., Sambudi N.S., Bilad M.R., Adeyemi I., Chakraborty S. \& Curcio S., 2021, Recent advances in advanced oxidation processes for removal of contaminants from water: A comprehensive review. Process Saf. Environ. Prot. 146: 220-256. https://doi.org/ https://doi.org/10.1016/j.psep.2020.08.015

Grenoble Z., Zhang C.C., Ahmed S., Jeffcoat S.B., Selbes M., Kaplan S.S., Begum S. \& Ahmad R., 2007, PhysicoChemical Processes 79: 1228-1296. https://doi. org/10.2175/106143007X218395

Guvenc S.Y., Dincer K. \& Varank G., 2019, Performance of electrocoagulation and electro-Fenton processes for treatment of nanofiltration concentrate of biologically stabilized landfill leachate. J. Water Process Eng. 31: 100863. https://doi.org/10.1016/j.jwpe.2019.100863

Han Y., Sun Y., Chen H., Guo X., Yu C., Li Y.B., Liu J. \& Xiao B., 2017, Effects of wastewater treatment processes on the sludge reduction system with 2,4-dichlorophenol: Sequencing batch reactor and anaerobic-anoxicoxic process. J. Biotechnol. 251: 99-105. https://doi. org/10.1016/j.jbiotec.2017.04.027

Hansen É., Monteiro de Aquim P. \& Gutterres M.,2021, Current technologies for post-tanning wastewater treatment: A review. J. Environ. Manage. 294: 113003. https://doi.org/ https://doi.org/10.1016/j.jenvman.2021.113003

Haq D.Z., Rini Novitasari D.C., Hamid A., Ulinnuha N., Farida Y., Nugraheni R.R.D., Nariswari R., Rohayani H., Pramulya R. \& Widjayanto A., 2021, Long Short-Term Memory Algorithm for Rainfall Prediction Based on El- 
Nino and IOD Data. Procedia Comput. Sci. 179: 829-837. https://doi.org/10.1016/j.procs.2021.01.071

Hassan M., Ashraf G.A., Zhang B., He Y., Shen G. \& Hu S., 2020, Energy-efficient degradation of antibiotics in microbial electro-Fenton system catalysed by M-type strontium hexaferrite nanoparticles. Chem. Eng. J. 380: 122483. https://doi.org/10.1016/j.cej.2019.122483

Holliger C., Gaspard S., Glod G., Heijman C., Schumacher W., Schwarzenbach R.P. \& Vazquez F., 1997, Contaminated environments in the subsurface and bioremediation: Organic contaminants. FEMS Microbiol. Rev. 20: 517523. https://doi.org/10.1016/S0168-6445(97)00030-2

Iqbal J., Hira P.R.,Al-Ali F. \& Philip R.,2001,Cryptosporidiosis in Kuwaiti children: seasonality and endemicity. Clinical microbiology and infection 7(5): 261-266. https://doi. org/10.1046/j.1198-743x.2001.00254.x.

Joseph C.G., Farm Y.Y., Taufiq-Yap Y.H., Pang C.K., Nga J.L.H. \& Puma G.L.,2021, Ozonation treatment processes for the remediation of detergent wastewater: A comprehensive review. J. Environ. Chem. Eng. 106099. https://doi.org/ https://doi.org/10.1016/j.jece.2021.106099

Karimi-Maleh H., Fakude C.T., Mabuba N., Peleyeju G.M. \& Arotiba O.A., 2019, The determination of 2-phenylphenol in the presence of 4-chlorophenol using nano-Fe3O4/ ionic liquid paste electrode as an electrochemical sensor. J. Colloid Interface Sci. 554: 603-610. https://doi. org/10.1016/j.jcis.2019.07.047

Keyan L., Jianan Z. \& Dayong D., 2021, Improving stock price prediction using the long short-term memory model combined with online social networks. J. Behav. Exp. Financ. 30: 100507. https://doi.org/10.1016/j. jbef.2021.100507

Khan A.H., Khan N.A., Ahmed S., Dhingra A., Singh C.P., Khan S.U., Mohammadi A.A., Changani F., Yousefi M., Alam S., Vambol S., Vambol V., Khursheed A. \& Ali I., 2020, Application of advanced oxidation processes followed by different treatment technologies for hospital wastewater treatment. J. Clean. Prod.269: 122411.https:// doi.org/10.1016/j.jclepro.2020.122411

Khan N.A., Ahmed S., Vambol V. \& Vambol S., 2021, Pharmaceutical Wastewater Treatment Technologies: Concepts and Implementation Strategies, 1st ed. IWA Publishing, UK.

Kimura K., Hara H. \& Watanabe Y., 2005, Removal of pharmaceutical compounds by submerged membrane bioreactors (MBRs). Desalination 178: 135-140. https:// doi.org/10.1016/j.desal.2004.11.033

Köhler C., Venditti S., Igos E., Klepiszewski K., Benetto E. \& Cornelissen A., 2012, Elimination of pharmaceutical residues in biologically pre-treated hospital wastewater using advanced UV irradiation technology: A comparative assessment. J. Hazard. Mater. 239-240: 70-77. https://doi. org/10.1016/j.jhazmat.2012.06.006

Kozak M., Cirık K., Dolaz M. \& Başak S., 2021, Evaluation of textile wastewater treatment in sequential anaerobic moving bed bioreactor - aerobic membrane bioreactor. Process Biochem. 105: 62-71. https://doi.org/10.1016/j. procbio.2021.03.013

Kulkarni S.J., Tapre R.W., Patil S.V. \& Sawarkar M.B., 2013, Adsorption of phenol from wastewater in fluidized bed using coconut shell activated carbon. Procedia Eng. 51: 300-307. https://doi.org/10.1016/j.proeng.2013.01.040

Kurian M., 2021, Advanced oxidation processes and nanomaterials -a review. Clean. Eng. Technol. 2: 100090. https://doi.org/https://doi.org/10.1016/j.clet.2021.100090

Lancheros J.C., Madera-Parra C.A., Caselles-Osorio A., Torres-López W.A. \& Vargas-Ramírez X.M., 2019, Ibuprofen and Naproxen removal from domestic wastewater using a Horizontal Subsurface Flow Constructed Wetland coupled to Ozonation. Ecol. Eng. 135: 89-97. https://doi. org/10.1016/j.ecoleng.2019.05.007

Ledjeri A., Yahiaoui I. \& Aissani-Benissad F., 2016, The electro/Fe3+/peroxydisulfate (PDS) process coupled to activated sludge culture for the degradation of tetracycline. J. Environ. Manage. 184: 249-254. https:// doi.org/10.1016/j.jenvman.2016.09.086

Lee Y., Kovalova L., McArdell C.S. \& von Gunten, U., 2014, Prediction of micropollutant elimination during ozonation of a hospital wastewater effluent. Water Res. 64: 134-148. https://doi.org/10.1016/j.watres.2014.06.027

Legrini O., Oliveros E. \& Braun A.M., 1993, Photochemical Processes for Water Treatment. Chem. Rev. 93: 671-698. https://doi.org/10.1021/cr00018a003

Li S., Hua T., Yuan C.S., Li B., Zhu X. \& Li F., 2020, Degradation pathways, microbial community and electricity properties analysis of antibiotic sulfamethoxazole by bio-electroFenton system. Bioresour. Technol. 298: 122501. https:// doi.org/10.1016/j.biortech.2019.122501

Li Y.-L., Chuang T.-W., Chang P., Su C.-T., Chien L.-N., Lin L.-Y. \& Chiou H.-Y., 2021, Long-term Exposure to Ozone and Sulfur Dioxide Increases the Incidence of Type 2 Diabetes Mellitus among Aged 30 to 50 adult population. Environ. Res. 194: 110624. https://doi.org/10.1016/j. envres.2020.110624

Li Y., Dong H., Li L., Tang L., Tian R., Li R., Chen J., Xie Q., Jin Z., Xiao J., Xiao S. \& Zeng G., 2021, Recent advances in waste water treatment through transition metal sulfides-based advanced oxidation processes. Water Res. 192: 116850. https://doi.org/https://doi.org/10.1016/j. watres.2021.116850

Liu L., Chen Z., Zhang J., Shan D., Wu Y., Bai L. \& Wang B., 2021, Treatment of industrial dye wastewater and pharmaceutical residue wastewater by advanced oxidation 
processes and its combination with nanocatalysts: A review. J. Water Process Eng. 42: 102122. https://doi. org/https://doi.org/10.1016/j.jwpe.2021.102122

Liu Z., Demeestere K. \& Van Hulle S., 2021, Comparison and performance assessment of ozone-based AOPs in view of trace organic contaminants abatement in water and wastewater: A review. J. Environ. Chem. Eng. 9: 105599. https://doi.org/https://doi.org/10.1016/j. jece.2021.105599

Lu S., Liu L., Demissie H., An G. \& Wang D., 2021, Design and application of metal-organic frameworks and derivatives as heterogeneous Fenton-like catalysts for organic wastewater treatment: A review. Environ. Int. 146: 106273. https://doi.org/https://doi.org/10.1016/j. envint.2020.106273

Luo H., Zeng Y., He D. \& Pan X., 2021, Application of ironbased materials in heterogeneous advanced oxidation processes for wastewater treatment: A review. Chem. Eng. J. 407: 127191. https://doi.org/https://doi.org/10.1016/j. cej.2020.127191

Mackulak T., Mosný M., Grabic R., Golovko O., Koba O. \& Birošová L., 2015, Fenton-like reaction: A possible way to efficiently remove illicit drugs and pharmaceuticals from wastewater. Environ. Toxicol. Pharmacol. 39: 483-488. https://doi.org/10.1016/j.etap.2014.12.016

Metropolitan Council Environmental Services, 2007, Recycling Treated Municipal Wastewater for Industrial Water Use. LCMR 05-07d MCES Project No. 070186 Prepared for Legislative Commission on Minnesota Resources. https://www.leg.mn.gov/docs/2007/ other/070575.pdf

Monteil H., Péchaud Y., Oturan N. \& Oturan M.A., 2019, A review on efficiency and cost effectiveness of electroand bio-electro-Fenton processes: Application to the treatment of pharmaceutical pollutants in water. Chem. Eng. J. 376: 119577. https://doi.org/10.1016/j. cej.2018.07.179

Mostafa M.K., Gamal G. \& Wafiq A., 2021, The impact of COVID 19 on air pollution levels and other environmental indicators - A case study of Egypt. J. Environ. Manage. 277: 111496. https://doi.org/10.1016/j.jenvman.2020.111496

Mouele E.S.M., Tijani J.O., Badmus K.O., Pereao O., Babajide O., Fatoba O.O., Zhang C., Shao T., Sosnin E., Tarasenko V., Laatikainen K. \& Petrik L.F., 2021, A critical review on ozone and co-species, generation and reaction mechanisms in plasma induced by dielectric barrier discharge technologies for wastewater remediation. J. Environ. Chem. Eng. 9: 105758. https://doi.org/https:// doi.org/10.1016/j.jece.2021.105758

Mozaffari N., Mozaffari N., Elahi S.M., Vambol S., Vambol V., Khan N.A. \& Khan N., 2020, Kinetics study of CO molecules adsorption on Al2O3/Zeolite composite films prepared by roll-coating method. Surf. Eng. 37(3): 1-10. https://doi.org/10.1080/02670844.2020.1768628

Paíga P., Santos L.H.M.L.M., Ramos S., Jorge S., Silva J.G. \& Delerue-Matos C., 2016, Presence of pharmaceuticals in the Lis river (Portugal): Sources, fate and seasonal variation. Sci. Total Environ. 573: 164-177. https://doi. org/10.1016/j.scitotenv.2016.08.089

Park J., Yamashita N. \& Tanaka H., 2018, Membrane fouling control and enhanced removal of pharmaceuticals and personal care products by coagulation-MBR. Chemosphere 197: 467-476. https://doi.org/10.1016/j. chemosphere.2018.01.063

Paumo H.K., Dalhatou S., Katata-Seru L.M., Kamdem B.P., Tijani J.O., Vishwanathan V., Kane A. \& Bahadur I., 2021, $\mathrm{TiO} 2$ assisted photocatalysts for degradation of emerging organic pollutants in water and wastewater. J. Mol. Liq. 331: 115458. https://doi.org/https://doi.org/10.1016/j. molliq.2021.115458

Qian X., Wang Y. \& Zheng H., 2016, Migration and distribution of water and organic matter for activated sludge during coupling magnetic conditioning-horizontal electro-dewatering (CM-HED). Water Res. 88: 93-103. https://doi.org/10.1016/j.watres.2015.10.001

Rekhate C.V. \& Srivastava J.K., 2020, Recent advances in ozone-based advanced oxidation processes for treatment of wastewater- A review. Chem. Eng. J. Adv. 3: 100031. https://doi.org/10.1016/j.ceja.2020.100031

Rivas F.J., Beltrán F.J. \& Encinas A., 2012, Removal of emergent contaminants: Integration of ozone and photocatalysis. J. Environ. Manage. 100: 10-15. https:// doi.org/10.1016/j.jenvman.2012.01.025

Rosset M., Sfreddo L.W., Hidalgo G.E.N., Perez-Lopez O.W. \& Féris L.A., 2019, Adsorbents derived from hydrotalcites for the removal of diclofenac in wastewater. Appl. Clay Sci. 175: 150-158. https://doi.org/10.1016/j.clay.2019.04.014

RS2, 2012, Potable water specification, 2nd ed. Rwanda Bureau of Standard, Kigali.

Sardana A., Cottrell B., Soulsby D. \& Aziz T.N., 2019, Dissolved organic matter processing and photoreactivity in a wastewater treatment constructed wetland. Sci. Total Environ. 648: 923-934. https://doi.org/10.1016/j. scitotenv.2018.08.138

Shirani Z., Song H. \& Bhatnagar A., 2020, Efficient removal of diclofenac and cephalexin from aqueous solution using Anthriscus sylvestris-derived activated biochar. Sci. Total Environ. 745: 140789. https://doi.org/https://doi. org/10.1016/j.scitotenv.2020.140789

Sipma J., Osuna B., Collado N., Monclús H., Ferrero G., Comas J. \& Rodriguez-Roda I., 2010, Comparison of removal of pharmaceuticals in MBR and activated sludge systems. Desalination 250: 653-659. https://doi. org/10.1016/j.desal.2009.06.073 
Soomro G.S., Qu C., Ren N., Meng S., Li X., Liang D., Zhang S. \& Li Y., 2020, Efficient removal of refractory organics in landfill leachate concentrates by electrocoagulation in tandem with simultaneous electro-oxidation and in-situ peroxone. Environ. Res. 183: 109249. https://doi. org/10.1016/j.envres.2020.109249

Souza F.S. \& Féris L.A., 2016, Hospital and Municipal Wastewater: Identification of Relevant Pharmaceutical Compounds. Water Environ. Res. 88: 871-877. https:// doi.org/10.2175/106143016x14609975747603

Tambosi J.L., de Sena R.F., Favier M., Gebhardt W., José H.J., Schröder H.F. \& de Fatima Peralta Muniz Moreira R., 2010, Removal of pharmaceutical compounds in membrane bioreactors (MBR) applying submerged membranes. Desalination 261(1-2): 148-156. https://doi. org/10.1016/j.desal.2010.05.014

Tete V.S., Nyoni H., Mamba B.B. \& Msagati T.A.M., 2020, Occurrence and spatial distribution of statins, fibrates and their metabolites in aquatic environments. Arab. J. Chem. 13: 4358-4373. https://doi.org/10.1016/j. arabjc.2019.08.003

Tripathi S. \& Hussain T., 2022, Water and Wastewater Treatment through Ozone-based technologies, Development in Wastewater Treatment Research and Processes. Elsevier Inc. https://doi.org/10.1016/b978-0323 -85583-9.00015-6

Verlicchi P., Al Aukidy M., Galletti A., Petrovic M. \& Barceló D., 2012, Hospital effluent: Investigation of the concentrations and distribution of pharmaceuticals and environmental risk assessment. Sci. Total Environ. 430: 109-118. https://doi.org/10.1016/j.scitotenv.2012.04.055

Vieira W.T., de Farias M.B., Spaolonzi M.P., da Silva M.G.C. \& Vieira M.G.A., 2021, Latest advanced oxidative processes applied for the removal of endocrine disruptors from aqueous media - A critical report. J. Environ. Chem. Eng. 9: 105748. https://doi.org/https://doi.org/10.1016/j. jece.2021.105748

Wang B., Shi W., Zhang H., Ren H. \& Xiong M., 2021, Promoting the ozone-liquid mass transfer through external physical fields and their applications in wastewater treatment: A review. J. Environ. Chem. Eng. 9: 106115. https:// doi.org/https://doi.org/10.1016/j.jece.2021.106115

Wang C.T., Chou W.L. \& Kuo Y.M., 2009, Removal of COD from laundry wastewater by electrocoagulation/ electroflotation. J. Hazard. Mater. 164: 81-86. https://doi. org/10.1016/j.jhazmat.2008.07.122

Wong T.W., Tam W.W.S., Yu I.T.S., Lau A.K.H., Pang S.W. \& Wong A.H.S., 2013, Developing a risk-based air quality health index. Atmos. Environ. 76: 52-58. https://doi. org/10.1016/j.atmosenv.2012.06.071

Xie Z.-H., Zhou H.-Y., He C.-S., Pan Z.-C., Yao G. \& Lai B., 2021, Synthesis, application and catalytic performance of layered double hydroxide based catalysts in advanced oxidation processes for wastewater decontamination: A review. Chem. Eng. J. 414: 128713. https://doi.org/ https://doi.org/10.1016/j.cej.2021.128713

Yan Y., Zhang H., Wang W., Li W., Ren Y. \& Li, X., 2021, Synthesis of $\mathrm{Fe} 0 / \mathrm{Fe} 3 \mathrm{O} 4 @$ porous carbon through a facile heat treatment of iron-containing candle soots for peroxymonosulfate activation and efficient degradation of sulfamethoxazole.J. Hazard. Mater. 411: 124952. https:// doi.org/https://doi.org/10.1016/j.jhazmat.2020.124952

Yang L., Liang X., Han Y., Cai Y., Zhao H., Sheng M. \& Cao G., 2019, The coupling use of advanced oxidation processes and sequencing batch reactor to reduce nitrification inhibition of industry wastewater: Characterization and optimization. Chem. Eng. J. 360: 1577-1586. https://doi. org/10.1016/j.cej.2018.10.232

Zolfaghari M., Jardak K., Drogui P., Brar S.K., Buelna G. \& Dubé R., 2016, Landfill leachate treatment by sequential membrane bioreactor and electro-oxidation processes. J. Environ. Manage. 184: 318-326. https://doi. org/10.1016/j.jenvman.2016.10.010

Zubair M., Daud M., McKay G., Shehzad F. \& Al-Harthi M.A., 2017, Recent progress in layered double hydroxides (LDH)-containing hybrids as adsorbents for water remediation. Appl. Clay Sci. 143: 279-292. https://doi. org/10.1016/j.clay.2017.04.002. 